\title{
Pengaruh Faktor Eksternal terhadap Sisa Makanan Pasien Di Ruang Cempaka RSUD Ibnu Sina Kabupaten Gresik
}

\author{
The Influence of External Factors on Patient's Food Waste In Hospital Cempaka \\ Lounge Ibnu Sina Gresik
}

\author{
Sonia Elka Amalia \\ Fakultas Kesehatan Masyarakat, Universitas Airlangga, Surabaya, Indonesia \\ soniaelkaamalia@gmail.com \\ DOI: http://doi.org/10.29080/jhsp.v4i1.331
}

Received: Januari 2020, Accepted:februari 2020, Published : April 2020

\begin{tabular}{l}
\hline Kata Kunci \\
\hline Sisa Makanan; \\
Pasien; \\
Rumah Sakit \\
\end{tabular}

\section{keywords}

Food waste;

Patient;

Hospital

\section{Abstrak}

Sisa makanan adalah makanan yang tidak habis dikonsumsi oleh pasien, dengan kategori banyak apabila sisa makanan $>20 \%$ dari makanan yang disajikan dan kategori sedikit apabila sisa makanan $\leq 20 \%$. Makanan yang disajikan oleh rumah sakit sudah disesuaikan dengan kebutuhan pasien, sehingga makanan dari rumah sakit menjadi salah satu penunjang proses penyembuhan pasien. Tujuan penelitian ini yaitu untuk menganalisis faktor yang mempengaruhi terjadinya sisa makanan pasien di Ruang Cempaka RSUD Ibnu Sina Kabupaten Gresik. Penelitian ini merupakan penelitian observasional analitik dengan menggunakan rancang bangun cross sectional. Jumlah sampel yang menjadi responden dalam penelitian ini berjumlah 65 responden. Penilaian sisa makanan menggunakan metode visual compstock. Data dianalisis menggunakan uji regresi logistik. Hasil penelitian menunjukkan bahwa menurut jenis makanan, yang paling banyak meninggalkan sisa adalah makanan pokok dan yang paling sedikit meninggalkan sisa makanan adalah buah. Penampilan makanan $(p=0,02)$ dan kesesuaian jadwal $(p=0,03)$ dapat mempengaruhi terjadinya sisa makanan. Sementara rasa makanan $(p=0,17)$, performa petugas $(p=0,94)$, suasana lingkungan $(p=0,52)$, dan makanan dari luar $(p=0,60)$ tidak mempengaruhi terjadinya sisa makanan.

\footnotetext{
Abstract

Food waste is food that is not consumed by patients, with a large category if wastes are $>20 \%$ of the food served and a small category if waste are $\leq 20 \%$. The food served by the hospital has been adapted to the needs of patients, so food from the hospital is one of the supporting processes for the patient's healing. The purpose of this study was to analyze the factors that influence the occurrence of patient's food waste in Cempaka Longue of Ibnu Sina Regional Hospital, Gresik Regency. This research was an observational analytic study using a cross sectional design. The number of samples that became respondents in this study amounted to 65 respondents. The assessment of patient's food waste uses the visual compstock. Data were analyzed using logistic regression test. The results showed that according to the type of food, the most patient's food waste were staple foods and the least left behind patient's food waste were fruit. Food appearance $(p=0,02)$ and suitability of schedule $(p=0,03)$ can influence the occurrence of patient's food waste. While the taste of food $(p=0,17)$, the performance of officers $(p=0,94)$, the environment $(p=0,52)$, and food from outside $(p=0,60)$ does not affect the occurrence of patient's food waste.
} 


\section{Pendahuluan}

Terapi gizi menjadi salah satu faktor penunjang utama penyembuhan dan harus diperhatikan agar tidak melebihi kemampuan organ tubuh selama proses metabolisme. Selama proses penyembuhan, terapi gizi akan selalu disesuaikan dengan perubahan fungsi organ. Pemberian diet pasien harus dievaluasi dan diperbaiki sesuai dengan perubahan keadaan klinis dan hasi pemeriksaan hasil laboratorium (1).

Peranan gizi dalam proses penyembuhan penyakit menjadi sangat penting pada masa sekarang ini. Menurut hasil penelitian yang dilakukan oleh Sunita Almatsier di beberapa Rumah Sakit di Jakarta (1991) menunjukan 20-60\% pasien mengalami gizi kurang saat dirawat di rumah sakit, dan hal ini disebabkan karena kurangnya asupan makanan pasien.

Pasien membutuhkan asupan zat gizi sesuai dengan kondisi pasien atau kebutuhan tubuh pasien (2). Hal ini sesuai dengan perilaku pemeliharaan kesehatan, yakni perilaku atau usaha-usaha seseorang untuk memelihara atau menjaga kesehatan agar tidak sakit dan usaha untuk penyembuhan bilamana sakit. Salah satu aspek dari perilaku pemeliharaan kesehatan yakni perilaku gizi (makanan) dan minuman. Makanan dan minuman dapat memelihara dan meningkatkan kesehatan seseorang, dan sebaliknya dapat menjadi penyebab menurunnya kesehatan seseorang bahkan dapat mendatangkan sakit (3).

Instalasi gizi akan memperhitungkan jumlah dan mutu gizi dari makanan yang disajikan, sehingga sehingga makanan tersebut harus dihabiskan pasien agar penyembuhan berjalan sesuai dengan program yang ditetapkan. Pasien yang tidak menghabiskan makanan dalam waktu yang lama dapat menyebabkan pasien mengalami defisiensi zat gizi. Hal ini menyebabkan tidak tercapainya pelayanan gizi (1).

Penilaian yang tepat terhadap status gizi sangat penting untuk menerapkan intervensi nutrisi yang efektif dan tepat waktu. Oleh karena itu, pemantauan status gizi pasien lebih penting untuk memastikan dukungan nutrisi yang tepat secara tepat waktu, untuk mencegah atau meminimalkan terjadinya kekurangan gizi (4).

Untuk mengetahui asupan zat gizi pada pasien yakni dengan dilakukannya evaluasi terhadap sisa makanan pasien (5). Sisa makanan adalah banyaknya makanan yang tidak dimakan. Sisa makanan terjadi karena pasien tidak menghabiskan makanan yang sudah diberikan. Sisa makanan dikatakan tinggi atau banyak jika pasien meninggalkan sisa makanan $\geq 20 \%$. Pasien yang menyisakan makanannya $\geq 20 \%$, dalam jangka waktu yang lama akan menyebabkan defisiensi zat-zat gizi (1).

Sisa makanan merupakan komponen yang sangat penting hal ini dapat menggambarkan asupan zatzat gizi dan tingginya tingkat sisa makanan dapat menyebabkan status kesehatan pasien yang semakin buruk. Tingginya sisa makanan pasien berhubungan dengan berkurangnya asupan energi dan protein, hal ini berdampak malnutrisi kepada pasien serta berkaitan dengan komplikasi.

Hasil dari beberapa studi menunjukkan bahwa terapi gizi yang optimal dapat memperbaiki hasil luaran klinis dan memangkas biaya perawatan kesehatan. Pada pelaksanaannya adanya kendala seperti kurangnya kesadaran gizi, kurangnya waktu, pembiayaan dan pelatihan, menyebabkan tidak optimalnya manajemen malnutrisi dan terapi gizi di rumah sakit. Kendala lain yang bisa terjadi yakni pada internal individu antara lain usia, kesulitan mengunyah, beratnya penyakit, efek samping obat, dan banyak faktor lain (6).

Sebelumnya telah dilakukan studi pendahuluan, dari data sisa makanan pasien yang ada di Rumah Sakit Umum Daerah Ibnu Sina Kabupaten Gresik pada bulan Januari-September 2018 didapatkan bahwa di beberapa ruang rawat inap masih belum tercapai dari target. Salah satu ruangan yang belum tercapai targetnya atau pasien masih menyisakan makanannya $>20 \%$ adalah Ruang Cempaka. Data rata-rata sisa makanan pasien yang ada di Ruang Cempaka menunjukkan pada bulan April sebanyak 22,18\%, bulan Mei 24,25\%, bulan Juni 24,58\%, bulan September 28,19\%. Ruang Cempaka merupakan ruang rawat inap untuk pasien penderita penyakit dalam. Di Ruang Cempaka terdiri dari berbagai penyakit dengan klasifikasi penyakit dalam, yakni Penyakit Ginjal Kronik, Jantung, Asma, Diabetes Mellitus, dan lainnya.

Terjadinya sisa makanan pasien dipengaruhi oleh faktor internal dan faktor eksternal. Faktor eksternal merupakan faktor yang berasal dari luar pasien, meliputi cita rasa makanan (penampilan makanan dan rasa makanan), performa petugas, kesesuaian jadwal makan, suasana lingkungan perawatan, dan makanan dari luar rumah sakit.

Penelitian ini bertujuan untuk mengetahui pengaruh faktor eksternal terhadap sisa makanan pasien di Ruang Cempaka RSUD Ibnu Sina Kabupaten Gresik.

\section{Metode Penelitian}

Penelitian ini merupakan penelitian observasional analitik dengan menggunakan rancang bangun cross sectional. Sampel dalam penelitian ini diambil dengan menggunakan metode purposive sampling dengan kriteria inklusi pasien dewasa berusia 18-64 tahun, pasien penerima diit makanan biasa dan lunak yang non diet dan diet khusus, pasien yang dirawat bisa diobservasi minimal tiga hari dan pasien bersedia menjadi responden. Jumlah sampel yang menjadi responden dalam penelitian ini berjumlah 65 responden. Penelitian ini dilakukan di Ruang Cempaka di RSUD Ibnu Sina Kabupaten Gresik. Penilaian sisa makanan menggunakan metode visual compstock dengan mengamati selama sembilan kali waktu makan. 
Untuk mengetahui faktor eksternal yang mempengaruhi terjadinya sisa makanan pasien menggunakan metode uji regresi logistik.

\section{Hasil Penelitian}

Distribusi responden berdasarkan jenis kelamin dan usia

Tabel 1. Distribusi Responden Berdasarkan Jenis Kelamin dan Usia

\begin{tabular}{|c|c|c|c|}
\hline No & Karakteristik & Frekuensi & Persentase (\%) \\
\hline \multirow[t]{3}{*}{1} & Jenis Kelamin & & \\
\hline & Laki-laki & 33 & 50,8 \\
\hline & Perempuan & 32 & 49,2 \\
\hline \multirow[t]{5}{*}{2} & Usia & & \\
\hline & Dewasa Awal (21-40 tahun) & 6 & 9,2 \\
\hline & Dewasa Tengah (41-60 tahun) & 39 & 60 \\
\hline & Dewasa Akhir ( $>60$ tahun) & 20 & 30,8 \\
\hline & Total & 65 & $100 \%$ \\
\hline
\end{tabular}

Pada tabel 1. Menunjukkan bahwa rata-rata responden berjenis kelamin laki-laki dengan persentase $50,8 \%$ dan rata-rata responden berusia 41-60 tahun dengan persentase $60 \%$.

Distribusi Sisa Makanan Pasien

Tabel 2. Distribusi Sisa Makanan Pasien

\begin{tabular}{ccc}
\hline Sisa Makanan Pasien & Jumlah & Persentase (\%) \\
\hline Banyak ( $>20 \%)$ & 42 & 64,6 \\
Sedikit ( $\leq 20 \%)$ & 23 & 35,4 \\
\hline Total & $\mathbf{6 5}$ & $\mathbf{1 0 0}$ \\
\hline
\end{tabular}

Sisa makanan pasien, terbanyak berada pada kategori banyak ( $>20 \%$ ) dengan jumlah 42 orang dengan persentase $64,6 \%$, sedangkan pada kategori sedikit sebanyak 23 orang dengan persentase 35,4\%.

a. Pengaruh Penampilan Makanan Terhadap Terjadinya Sisa Makanan Pasien

Tabel 3. Pengaruh Penampilan Makanan Terhadap Terjadinya Sisa Makanan Pasien

\begin{tabular}{lccccccc}
\hline \multirow{2}{*}{$\begin{array}{c}\text { Penampilan } \\
\text { Makanan }\end{array}$} & \multicolumn{4}{c}{ Sisa Makanan Pasien } & \multicolumn{2}{c}{ Total } & \multirow{2}{*}{$\boldsymbol{P}$} \\
\cline { 2 - 6 } & \multicolumn{2}{c}{ Banyak } & $\mathbf{c}$ Sedikit & & \\
\cline { 2 - 7 } & $\mathbf{n}$ & $\mathbf{\%}$ & $\mathbf{N}$ & $\mathbf{\%}$ & $\mathbf{N}$ & $\mathbf{\%}$ & \\
\hline Menarik & 16 & 48,5 & 17 & 51,5 & 33 & 100 & 0,02 \\
Kurang Menarik & 26 & 81,3 & 6 & 18,8 & 32 & 100 & \\
\hline
\end{tabular}

Berdasarkan Tabel 3. Didapatkan bahwa mayoritas responden menyatakan bahwa penampilan makanan kurang menarik $(81,3 \%)$ dan menimbulkan sisa makanan pasien masuk pada kategori banyak. Hasil dari perhitungan diperoleh nilai p-value sebesar 0,02 yang menunjukkan bahwa nilai tersebut lebih kecil dari level of significan $\alpha=0,05$, maka dapat disimpulkan bahwa ada pengaruh penampilan makanan terhadap terjadinya sisa makanan pasien.

b. Pengaruh Rasa Makanan Terhadap Terjadinya Sisa Makanan Pasien

Tabel 4. Pengaruh Rasa Makanan Terhadap Terjadinya Sisa Makanan Pasien

\begin{tabular}{lccccccc}
\hline \multirow{2}{*}{ Rasa Makanan } & \multicolumn{3}{c}{ Sisa Makanan Pasien } & \multicolumn{2}{c}{ Total } & \multirow{2}{*}{$\boldsymbol{P}$} \\
\cline { 2 - 6 } & \multicolumn{3}{c}{ Banyak } & \multicolumn{2}{c}{ Sedikit } & & \\
\cline { 2 - 7 } & $\mathbf{n}$ & $\mathbf{\%}$ & $\mathbf{N}$ & $\mathbf{\%}$ & $\mathbf{N}$ & $\mathbf{\%}$ & \\
\hline Enak & 19 & 55,9 & 15 & 44,1 & 34 & 100 & 0,17 \\
Kurang Enak & 23 & 74,2 & 8 & 25,8 & 31 & 100 & \\
\hline
\end{tabular}

Pada Tabel 4. Didapatkan bahwa mayoritas responden menyatakan rasa makanan kurang enak $(74,2 \%)$ dan menimbulkan sisa makanan pasien masuk pada kategori banyak. Hasil dari perhitungan 
diperoleh nilai p-value sebesar 0,17 yang menunjukkan bahwa nilai tersebut lebih besar dari level of significan $\alpha=0,05$, maka dapat disimpulkan bahwa tidak ada pengaruh rasa makanan terhadap terjadinya sisa makanan pasien.

c. Pengaruh Performa Petugas Terhadap Terjadinya Sisa Makanan Pasien

Tabel 5. Pengaruh Performa Petugas Terhadap Terjadinya Sisa Makanan Pasien

\begin{tabular}{lccccccc}
\multirow{2}{*}{$\begin{array}{c}\text { Performa } \\
\text { Petugas }\end{array}$} & \multicolumn{4}{c}{ Sisa Makanan } & \multicolumn{2}{c}{ Total } & \multirow{2}{*}{$\boldsymbol{P}$} \\
\cline { 2 - 6 } & \multicolumn{2}{c}{ Banyak } & \multicolumn{2}{c}{ Sedikit } & & \\
\cline { 2 - 7 } & $\mathbf{n}$ & $\mathbf{\%}$ & $\mathbf{N}$ & $\mathbf{\%}$ & $\mathbf{n}$ & $\mathbf{\%}$ & \\
\hline Baik & 19 & 63,3 & 11 & 36,7 & 30 & 100 & 0,94 \\
Kurang Baik & 23 & 65,7 & 12 & 34,3 & 35 & 100 &
\end{tabular}

Pada Tabel 5. Didapatkan bahwa mayoritas responden menyatakan performa petugas kurang baik $(65,7 \%)$ dan menimbulkan sisa makanan pasien masuk pada kategori banyak. Hasil dari perhitungan diperoleh nilai p-value sebesar 0,94 yang menunjukkan bahwa nilai tersebut lebih besar dari level of significan $\alpha=0,05$, maka dapat disimpulkan bahwa tidak ada pengaruh performa petugas terhadap terjadinya sisa makanan pasien.

d. Pengaruh Kesesuaian Jadwal Makan Terhadap Terjadinya Sisa Makanan Pasien

Tabel 6. Pengaruh Kesesuaian Jadwal Makan Terhadap Terjadinya Sisa Makanan Pasien

\begin{tabular}{|c|c|c|c|c|c|c|c|}
\hline \multirow{3}{*}{$\begin{array}{c}\text { Kesesuaian } \\
\text { Jadwal Makan }\end{array}$} & \multicolumn{4}{|c|}{ Sisa Makanan } & \multirow{2}{*}{\multicolumn{2}{|c|}{ Total }} & \multirow[t]{3}{*}{$P$} \\
\hline & \multicolumn{2}{|c|}{ Banyak } & \multicolumn{2}{|c|}{ Sedikit } & & & \\
\hline & $\mathbf{n}$ & $\%$ & $\mathbf{N}$ & $\%$ & $\mathbf{n}$ & $\%$ & \\
\hline Sesuai Jadwal & 32 & 76,2 & 10 & 23,8 & 42 & 100 & 0,03 \\
\hline $\begin{array}{l}\text { Tidak Sesuai } \\
\text { Jadwal }\end{array}$ & 10 & 43,5 & 13 & 56,5 & 23 & 100 & \\
\hline
\end{tabular}

Pada Tabel 6. Didapatkan bahwa mayoritas responden menyatakan kesesuaian jadwal makan sesuai jadwal $(76,2 \%)$ dan menimbulkan sisa makanan pasien masuk pada kategori banyak. Hasil dari perhitungan diperoleh nilai p-value sebesar 0,03 yang menunjukkan bahwa nilai tersebut lebih besar dari level of significan $\alpha=0,05$, maka dapat disimpulkan bahwa ada pengaruh kesesuaian jadwal makan terhadap terjadinya sisa makanan pasien.

e. Pengaruh Suasana Lingkungan Perawatan Terhadap Terjadinya Sisa Makanan Pasien

Tabel 7. Pengaruh Suasana Lingkungan Perawatan Terhadap Terjadinya Sisa Makanan Pasien

\begin{tabular}{lccccccc}
\hline \multirow{2}{*}{$\begin{array}{c}\text { Suasana } \\
\text { Lingkungan } \\
\text { Perawatan }\end{array}$} & \multicolumn{3}{c}{ Sisa Makanan } & \multicolumn{3}{c}{ Total } & \multirow{2}{*}{$\boldsymbol{P}$} \\
\cline { 2 - 6 } & $\mathbf{n}$ & $\mathbf{\%}$ & $\mathbf{N}$ & $\mathbf{\%}$ & $\mathbf{n}$ & $\mathbf{\%}$ & \\
\hline Baik & 27 & 62,8 & 16 & 37,2 & 43 & 100 & 0,52 \\
Tidak Baik & 15 & 68,2 & 7 & 31,8 & 22 & 100 &
\end{tabular}

Pada Tabel 7. Didapatkan bahwa mayoritas responden menyatakan suasana lingkungan perawatan baik $(62,8 \%)$ dan menimbulkan sisa makanan pasien masuk pada kategori banyak. Hasil dari perhitungan diperoleh nilai p-value sebesar 0,52 yang menunjukkan bahwa nilai tersebut lebih besar dari level of significan $\alpha=0,05$, maka dapat disimpulkan bahwa tidak ada pengaruh suasana lingkungan perawatan terhadap terjadinya sisa makanan pasien.

f. Pengaruh Makanan dari Luar Rumah Sakit Terhadap Terjadinya Sisa Makanan Pasien

Tabel 8. Pengaruh Makanan dari Luar Rumah Sakit Terhadap Terjadinya Sisa Makanan Pasien

\begin{tabular}{|c|c|c|c|c|c|c|c|}
\hline \multirow{3}{*}{$\begin{array}{l}\text { Makanan dari Luar } \\
\text { Rumah Sakit }\end{array}$} & \multicolumn{4}{|c|}{ Sisa Makanan } & \multirow{2}{*}{\multicolumn{2}{|c|}{ Total }} & \multirow[t]{3}{*}{$P$} \\
\hline & \multicolumn{2}{|c|}{ Banyak } & \multicolumn{2}{|c|}{ Sedikit } & & & \\
\hline & $\mathbf{n}$ & $\%$ & $\mathbf{n}$ & $\%$ & $\mathbf{n}$ & $\%$ & \\
\hline Pernah Mengonsumsi & 25 & 64,1 & 14 & 35,9 & 39 & 100 & 0,60 \\
\hline $\begin{array}{l}\text { Tidak Pernah } \\
\text { Mengonsumsi }\end{array}$ & 17 & 65,4 & 9 & 34,6 & 26 & 100 & \\
\hline
\end{tabular}


Pada Tabel 8. Didapatkan bahwa mayoritas responden menyatakan pernah mengonsumsi makanan dari luar rumah sakit $(64,1 \%)$ dan menimbulkan sisa makanan pasien masuk pada kategori banyak. Hasil dari perhitungan diperoleh nilai p-value sebesar 0,60 yang menunjukkan bahwa nilai tersebut lebih besar dari level of significan $\alpha=0,05$, maka dapat disimpulkan bahwa tidak ada pengaruh makanan dari luar rumah sakit terhadap terjadinya sisa makanan pasien.

\title{
Pembahasan
}

\author{
a. Sisa Makanan Pasien
}

Sisa makanan pasien adalah makanan yang tidak habis dimakan setelah disajikan ke pasien. Sisa makanan dikatakan banyak apabila $>20 \%$ dan sedikit apabila $\leq 20 \%$. Dalam penelitian ini, untuk mengetahui banyaknya makanan yang tidak dikonsumsi dilakukan dengan menggunakan metode visual compstock atau taksiran visual, yaitu dengan melihat secara langsung sisa makanan yang berada dipiring saji.

Berdasarkan hasil penelitian yang dilakukan pada 65 pasien yang menjadi responden di Ruang Cempaka RSUD Ibnu Sina Kabupaten Gresik didapatkan persentase rata-rata sisa makanan sebesar 48,58\%. Hal ini menunjukkan bahwa rata-rata sisa makanan pasien masuk ke dalam kategori banyak, karena rata-rata sisa makanan $>20 \%$.

Menurut jenis makanan, yang paling banyak meninggalkan sisa adalah makanan pokok dan yang paling sedikit meninggalkan sisa makanan adalah buah. Jenis makanan yang memiliki persentase sisa makanan paling banyak adalah makanan pokok yaitu sebesar 57,48\%. Sedangkan jenis makanan yang memiliki persentasi sisa makanan paling sedikit adalah buah dan snack dengan rata-rata sisa makanan sebesar $0 \%$.

Persentase rata-rata sisa makanan paling banyak yang ditinggalkan oleh responden adalah sebesar $100 \%$, artinya makanan yang disajikan dari rumah sakit tidak dimakan sama sekali. Sedangkan persentase sisa makanan paling sedikit sebesar $0 \%$, artinya tidak ada sisa makanan.

Hasil penelitian ini sesuai dengan penelitian terdahulu yang menyatakan bahwa sisa makanan paling banyak pada pasien rawat inap di Rumah Sakit Islam Jemursari Surabaya yaitu sebanyak 31,73\%. Hal tersebut menggambarkan bahwa sisa makanan pokok paling banyak adalah makanan pokok, ini dikarenakan makanan pokok seringkali tidak disukai saat seseorang sedang sakit, sehingga meninggalkan banyak sisa daripada jenis makanan yang lain (7).

Berdasarkan penelitian terdahulu menunjukkan hasil bahwa buah merupakan sisa makanan paling sedikit yaitu sebesar 19,47\%. Dimana hasil penelitian terdahulu ini juga sesuai dengan hasil penelitian yang dilakukan oleh peneliti. Buah lebih bisa dikonsumsi oleh pasien karena memiliki aneka rasa dari pada jenis makanan lainnya seperti nasi. Hal tersebut menjadikan buah menjadi jenis makanan dengan sisa paling sedkit daripada jenis makanan lain (8).

b. Pengaruh Penampilan Makanan Terhadap Terjadinya Sisa Makanan Pasien

Penampilan makanan adalah penampakan dari makanan yang dihidangkan. Penampilan makanan meliputi warna makanan, bentuk makanan, porsi makanan, dan penyajian makanan. Penyajian makanan di Ruang Cempaka RSUD Ibnu Sina Kabupaten Gresik disesuaikan dari kelas perawatannya yaitu kelas III. Pada kelas III makanan disajikan pada plato yang terdapat sekat untuk memisahkan tiap jenis makanan kemudian di tutup menggunakan pembungkus plastik, sehingga saat makanan tersebut dapat disajikan dalam keadaan bersih, rapi, dan tidak tercampur saat dihidangkan kepada pasien.

Berdasarkan hasil penelitian didapatkan bahwa penampilan makanan dapat mempengaruhi terjadinya sisa makanan pasien. Hal ini dapat dibuktikan dari perhitungan dengan hasil nilai p 0,02 yang menunjukkan bahwa nilai tersebut lebih kecil dari level of significan $\alpha=0,05$ ( $\mathrm{p}$-value $<0,05$ ). Maka dapat disimpulkan bahwa ada pengaruh penampilan makanan terhadap terjadinya sisa makanan pasien di Ruang Cempaka RSUD Ibnu Sina Kabupaten Gresik.

Penampilan makanan merupakan hal pertama yang dilihat responden ketika makanan disajikan. Penampilan makan yang meliputi warna makanan, bentuk, besar porsi, dan cara penyajian dianggap kurang menarik bagi responden, sehingga penampilan makanan menjadi faktor yang mempengaruhi terjadinya sisa makanan. Penelitian ini sejalan dengan penelitian yang dilakukan di RSUD Kota Semarang, bahwa Penampilan makanan yang meliputi warna, porsi, bentuk, tekstur, alat yang digunakan, dan cara penyusunan makanan, menunjukkan adanya hubungan dengan sisa makanan $(\mathrm{p}=0,044)(11)$.

Hasil penelitian ini juga sejalan dengan penelitian yang dilakukan di Rumah Sakit Angkatan Laut Dr. Ramelan Surabaya, bahwa penampilan makanan berhubungan dengan sisa makanan, sehingga semakin baik penilaian responden terhadap penampilan makanan maka semakin sedikit pula pasien menyisakan makanannya. Dimana ditemukan hubungan antara penampilan makanan dengan sisa 
makanan $(\mathrm{p}=0,046)(12)$.

c. Pengaruh Rasa Makanan Terhadap Terjadinya Sisa Makanan Pasien

Rasa makanan adalah rasa yang ditimbulkan dari makanan yang disajikan. Rasa makanan meliputi aroma makanan, bumbu masakan, tingkat kematangan, suhu makanan dan tekstur makanan. Berdasarkan Hasil penelitian didapatkan bahwa rasa makanan tidak mempengaruhi terjadinya sisa makanan. Hal ini dibuktikan dengan uji statistik menggunakan dengan hasil nilai p 0,17 yang menunjukkan bahwa nilai tersebut lebih kecil dari level of significan $\alpha=0,05$ ( $p$-value $<0,05$ ). Maka dapat disimpulkan bahwa tidak ada pengaruh rasa makanan terhadap terjadinya sisa makanan di Ruang Cempaka RSUD Ibnu Sina Kabupaten Gresik.

Menurut keterangan dari responden, rasa makanan yang meliputi aroma makanan, bumbu makanan, tingkat kematangan, suhu makanan, dan tekstur makanan sudah baik. Penelitian ini sejalan dengan Nareswara (2017) yang menyatakan bahwa tidak ada hubungan antara kepuasan pasien terhadap rasa dengan sisa makanan $(p=0,127)$. Penelitian yang dilakukan di ruang rawat inap RSUD Dr. H. Abdul Moeloek Provinsi Lampung juga menyatakan bahwa tidak ada hubungan antara cita rasa responden dengan sisa makanan $(\mathrm{p}=1,000)(13)$.

\section{d. Pengaruh Performa Petugas Terhadap Sisa Makanan Pasien}

Berdasarkan hasil penelitian menunjukkan bahwa performa petugas tidak mempengaruhi terjadinya sisa makanan. Hal ini dibuktikan dengan uji statistik menggunakan dengan hasil nilai p 0,94 yang menunjukkan bahwa nilai tersebut lebih kecil dari level of significan $\alpha=0,05$ ( $p$-value $<0,05$ ). Maka dapat disimpulkan bahwa tidak ada pengaruh rasa makanan terhadap terjadinya sisa makanan di Ruang Cempaka RSUD Ibnu Sina Kabupaten Gresik.

Menurut keterangan responden, peforma petugas di Ruang Cempaka RSUD Ibnu Sina Kabupaten Gresik dalam kategori baik. Oleh karena itu terdapat faktor lain yang lebih kuat untuk mempengaruhi terjadinya sisa makanan daripada performa petugas. Sementara penelitian terdahulu yang ditemukan oleh peneliti performa petugas mempengaruhi sisa makanan di rumah sakit. Hal tersebut dikarenakan sikap petugas pada rumah sakit kurang baik, sehingga menyebabkan adanya sisa makanan (14).

e. Pengaruh Kesesuaian Jadwal Makan Terhadap Terjadinya Sisa Makanan Pasien

Berdasarkan hasil penelitian menunjukkan bahwa kesesuaian jadwal dapat mempengaruhi terjadinya sisa makanan. Hal ini dibuktikan dengan uji statistik menggunakan dengan hasil nilai p 0,03 yang menunjukkan bahwa nilai tersebut lebih kecil dari level of significan $\alpha=0,05$ ( $\mathrm{p}$-value $<0,05$ ). Maka dapat disimpulkan bahwa ada pengaruh kesesuaian jadwal makan terhadap terjadinya sisa makanan di Ruang Cempaka RSUD Ibnu Sina Kabupaten Gresik.

Menurut pendapat responden, jadwal dihidangkan makan pagi terlalu siang yakni pukul 07.00 WIB. Pada pukul 07.00 WIB responden akan merasakan lapar sebelum makanan dihidangkan. Hal ini dikarenakan jadwal dihidangkan makanan untuk malam hari yaitu pukul 17.00 WIB sehingga jarak waktu untuk makan pagi terlalu jauh.

Hal ini sejalan dengan penelitian dengan berjudul "Hubungan Ketepatan Waktu Penyajian dan Mutu Makanan dengan Sisa Makanan Pasien Dewasa Non Diet Di RSU PKU Muhammadiyah Bantul” yang menyatakan bahwa ketepatan waktu penyajian makanan memiliki hubungan yang bermakna dengan sisa makanan dengan pvalue 0,019<0,05 (15).

\section{f. Pengaruh Suasana Lingkungan Perawatan Pasien Terhadap Terjadinya Sisa Makanan Pasien}

Berdasarkan hasil penelitian menunjukkan bahwa suasana lingkungan perawatan tidak mempengaruhi terjadinya sisa makanan. Hal ini dapat dibuktikan dari uji statistik dengan hasil nilai $\mathrm{p}$ 0,52 yang menunjukkan bahwa nilai tersebut lebih kecil dari level of significan $\alpha=0,05$ ( $\mathrm{p}$-value $<$ 0,05). Maka dapat disimpulkan bahwa tidak ada pengaruh suasana lingkungan perawatan terhadap terjadinya sisa makanan di Ruang Cempaka RSUD Ibnu Sina Kabupaten Gresik.

Ruang Cempaka merupakan ruang perawatan kelas III, sehingga beberapa responden tidak merasa terganggu dengan suasana di lingkungan perawatan jika disesuaikan dengan kemampuan ekonominya. Suasana lingkungan perawatan yang meliputi kebersihan ruangan, ketenangan ruangan, dan fasilitas umum ruang perawatan tidak mempengaruhi terjadinya sisa makanan.

Hal ini sejalan dengan penelitian yang menyatakan bahwa kebersihan tidak ada pengaruh antara kebersihan dengan terjadinya sisa makanan di Ruang Penyakit Dalam di RSUD Cut Nyak Dhien Meulaboh dengan p value $0,679(\alpha=0,05)(9)$.

g. Pengaruh Makanan dari Luar Rumah Sakit Terhadap Terjadinya Sisa Makanan Pasien 
Berdasarkan hasil penelitian menunjukkan bahwa makanan dari luar rumah sakit tidak mempengaruhi terjadinya sisa makanan. Hal ini dibuktikan dengan uji statistik menggunakan dengan hasil nilai p 0,60 yang menunjukkan bahwa nilai tersebut lebih besar dari level of significan $\alpha=0,05$ ( $p$ value $<0,05$ ). Maka dapat disimpulkan bahwa tidak ada pengaruh makanan luar rumah sakit terhadap terjadinya sisa makanan di Ruang Cempaka RSUD Ibnu Sina Kabupaten Gresik.

Beberapa responden mengidap penyakit dalam seperti penyakit ginjal kronik, jantung, diabetes, dan lainnya, sehingga membutuhkan diet makanan khusus. Oleh karena itu responden akan lebih mematuhi mengonsumsi diet makanan khusus dan tidak sembarang mengonsumsi makanan lainnya yang menjadi pantangan. Pasien PGK yang menjalani terapi hemodialisis yang merasa terancam kesehatannya oleh penyakit yang diderita maka kepercayaannya terhadap program diet hemodialisis yang diberikan akan memunculkan sikap baik sehingga cenderung untuk berperilaku patuh (16).

Berdasarkan hasil penelitian yang dilakukan di Rumah Sakit Tentara dr. Soepraoen Malang menjelaskan bahwa adanya makanan tambahan dari luar tidak mempengaruhi sisa makanan pasien. Hal ini dikarenakan pasien yang tidak mendapatkan asupan makanan tambahan dari luar hanya mengandalkan asupan dari diet yang diberikan rumah sakit, sedangkan pasien yang mendapatkan makanan tambahan dari luar menyisakan sisa makanan yang banyak karena bentuk makanan tambahan dari luar yang dikonsumsi juga kaya akan karbohidrat, lauk hewani, lauk nabati, sayuran dan buah (17).

\section{Simpulan dan Saran}

Terdapat beberapa faktor yang mempengaruhi terjadinya sisa makanan pasien di Ruang Cempaka RSUD Ibnu Sina Kabupaten Gresik, yaitu penampilan makanan dan kesesuaian jadwal makan. Peralatan makan untuk kelas III yang menggunakan plato perlu diganti menjadi peralatan makan biasa seperti piring, mangkok, dan sendok sehingga pasien akan merasa bahwa penampilan makanan tersebut tidak seperti makanan rumah sakit melainkan sama dengan makanan yang biasa dikonsumsi. Untuk jadwal makan dapat diperbaiki dengan menyesuaikan waktu makan yang biasa dilakukan pasien terutama pada waktu makan pagi.

\section{Daftar Pustaka}

1. Depkes. Pedoman Pelayanan Gizi Rumah Sakit. 2013.

2. Ratna MR. Evaluasi Manajemen Penyelenggaraan Makanan Institusi di Rumah Sakit Ortopedi Prof. Dr. R. Soeharso Surakarta. Universitas Muhammadiyah Surakarta; 2009.

3. Notoatmodjo S. Promosi Kesehatan dan Perilaku Kesehatan. Jakarta: Rineka Cipta; 2012.

4. Adikari A. Nutritional Status of In-patients with Chronic Kidney Diseases in Sri Lanka. Hum Biol Rev. 2016;247-54.

5. Barker, L. A., Gout, B. S., \& Crowe TC. Hospital Malnutrition: Prevalence, Identification and Impact on Patients and the Healthcare System. Int J Environ Res Public Heal. 2011;514-27.

6. Mulyati S. Sadar Gizi Dalam Lingkup Rumah Sakit. CDK-248. 2017;44(1):58-64.

7. Habiba RA, Adriani M. Hubungan Depresi , Asupan, dan Penampilan Makanan dengan Sisa Makan Pagi Pasien Rawat Inap ( Studi di Rumah Sakit Islam Jemursari Surabaya ) Association between Depression , Intake, and Appearance of Food with the Morning Food Waste among Inpatients ( S. Amerta Nutr. 2017;198-208.

8. Julia D. Hubungan Daya Terima Makanan dengan Biaya Sisa Makanan pada Pasien Skizofrenia. Darussalam Nutr J. 2018;2(1):19.

9. Andani A. Faktor-faktor yang Mempengaruhi Terjadinya Sisa Makanan Pada Pasien Rawat Inap Di Ruang Penyakit Dalam RSUD Cut Nyak Dhien Meulaboh. Universitas Teuku Umar Meulaboh; 2013.

10. Karunia Tanuwijaya L, Gresari Sembiring L, Yanuar Dini C, Putri Arfiani E, Arimba Wani Y. Sisa Makanan Pasien Rawat Inap: Analisis Kualitatif. Indones J Hum Nutr. 2018;5(1):51-61.

11. Nareswara AS. Hubungan Kepuasan Pasien dari Kualitas Makanan Rumah Sakit dengan Sisa Makanan Di RSUD Kota Semarang. Ilmu Gizi Indones. 2017;1(1):34-9.

12. Kartini RF, Primadona S. Open Access Hubungan Bentuk, Rasa Makanan, dan Cara Penyajian dengan Sisa Makanan Selingan Pada Pasien Anak di Rumah Sakit Angkatan Laut Dr. Ramelan Surabaya Correlation between the Form , Taste, Serving Method of Snacks and Plate Waste among Pediatri. 2018;212-8.

13. Muliani. Faktor-Faktor Yang Berhubungan Dengan Sisa Makanan Saring Pasien Rawat Inap. 2013;Jurnal Keperawatan;IX(1):31-6.

14. Ronitawati P, Puspita M, Citra K, Gizi PS, Kesehatan FI, Unggul UE, et al. Faktor-Faktor Yang Berhubungan Dengan Sisa Makanan Di Rumah Sakit Umum Daerah Koja Jakarta Utara Tahun 2017. J 
Kesehat. 2017;57-76.

15. Rina A. Hubungan Ketepatan Waktu Penyajian dan Mutu Makanan dengan Sisa Makanan Pasien Dewasa Non Diet di RSU PKU Muhammadiyah Bantul. Poltekkes Kemenkes Yogyakarta; 2017.

16. Mardjun F. Faktor yang berhubungan dengan kepatuhan pembatasan asupan cairan pada pasien gagal ginjal kronik di ruang hemodialisa RSUD Prof. Dr. H. Aloei Saboe Kota Gorontalo. Universitas Negeri Gorontalo; 2014.

17. Kumboyono V. Indikator Pemenuhan Kebutuhan Nutrisi oleh Pasien Rawat Inap Rumah Sakit Tentara dr. Soepraoen Malang. Jurnal Ners. 2013;8(2):183-9. 